\title{
Determination of Phosphodiesterase Type 5 Enzyme (PDE-5) Inhibitors and Analogues as Adulterants in Selected Herbal Products using Gas Chromatography-Electron Impact-Mass Spectrometer (GC-EI-MS)
}

\author{
Nur Azzalia Kamaruzaman ${ }^{*^{*}}$ \\ Mazlin Mohideen ${ }^{2}$ \\ Azaharudin Awang Ahmad \\ Norjuliana Mohd Noor ${ }^{1}$
}

\begin{abstract}
${ }^{1}$ National Poison Centre, Universiti Sains Malaysia, 11800 Penang, Malaysia
${ }^{2}$ Faculty of Pharmacy and Health Sciences, Universiti Kuala Lumpur-Royal College of Medicine Perak (UniKLRCMP), 30450 Ipoh, Perak, Malaysia

*Corresponding author: azzalia@usm.my*,mazlin.mohideen@unikl.edu.my; yhleong@usm.my; azaharudin@usm.my ; julianamnoor@usm.my

"ORCID ID: https://orcid.org/0000-0002-6846-1642*,https://orcid.org/0000-0003-3483-7493; https://orcid.org/00000001-6767-6425; https://orcid.org/0000-0002-0882-5117 ; https://orcid.org/0000-0002-1171-1639
\end{abstract}

Received 20/10/2019, Accepted 1/4/2020, Published 1/12/2020

This work is licensed under a Creative Commons Attribution 4.0 International License.

\begin{abstract}
:
Sildenafil, tadalafil, and vardenafil are phosphodiesterase type 5 enzyme (PDE-5) inhibitors used for the treatment of male erectile dysfunction. This present study aims to investigate 55 herbal products indicated for men's sexual health from the Malaysian market for adulteration of PDE-5 inhibitors and analogues. The screening and identification of 20 PDE-5 inhibitors and analogues in herbal products of various forms (powder, capsules, tablets, and pastels) were conducted using gas chromatography-electron impact-mass spectrometer (GC-EI-MS). The analysis has shown that 19 herbal products were adulterated with PDE-5 inhibitors and analogues. Unique ion fragmentations and the presence of molecular ion serve as potential markers, and the limit of detection (LOD) was 0.1-5.0 $\mu \mathrm{g} / \mathrm{g}$. Ten PDE-5 inhibitors and analogues were randomly selected and successfully validated for simultaneous quantification, whereby the limit of quantitation (LOQ) was 5.0-50.0 $\mu \mathrm{g} / \mathrm{g}$ with recoveries at 86.1-118.9\%. The developed method of GC-EI-MS was shown to be simple, throughput, economical and had sufficient sensitivity to screen, identify and quantify PDE-5 inhibitors and analogues in herbal matrices.
\end{abstract}

Key words: Adulteration, Chromatography-electron impact-mass spectrometer (GC-EI-MS), Herbal products, Men's sexual health, Phosphodiesterase type 5 enzyme (PDE-5) inhibitors.

\section{Introduction:}

Adulteration of phosphodiesterase type 5 enzyme (PDE-5) inhibitors in herbal supplements and food products has been a public health concern in many countries around the world (1-4), including Malaysia. For surveillance and monitoring, Control of Drugs and Cosmetics Regulations 1984 was enacted by the Malaysian government to enforce all herbal products that are manufactured, imported and sold in the country to be tested for the presence of adulterants, before registration with the Drug Control Authority of Malaysia (DCA). Unfortunately, even with law enforcement, adulteration of PDE-5 inhibitors in herbal preparations is still prevalent in the Malaysian market (5).
As of currently, sildenafil, tadalafil, vardenafil, and udenafil are the only synthetic PDE5 inhibitors approved by the Ministry of Health Malaysia (MOH) for the treatment of male erectile dysfunction (5). The prescription of PDE-5 inhibitors is fully controlled due to the harmful sideeffects from the vasodilation nature of PDE-5 inhibitors on the pulmonary vessels. The use of PDE-5 inhibitors is also contraindicated in patients prescribed with antihypertensive such as nitrates as well as untreated patients with hypotension (6).

Certain herbal products are marketed to be 'natural' sexual enhancers for men. Demand for these products is high as the public mistakenly associate them as safer than prescription medicine due to claims of all-natural ingredients $(4,7)$. In 
addition, some consumers may feel embarrassed about their health situation and feel more comfortable with the purchase of these herbal products which are easily more accessible rather than consulting with a medical professional (5). To keep up with the demand for 'natural' aphrodisiacs and to avoid regulatory inspection, errant manufacturers and suppliers have begun synthesizing PDE-5 inhibitor analogues of sildenafil, tadalafil and vardenafil $(5,8)$. The analogues are synthesized using various chemical modifications of the parent compounds, thus resulting in the unpredictability of potency, side effects, and toxicity (9). Many reports have shown that some commercially available herbal products are adulterated with approved PDE-5 inhibitors as well as unapproved analogues $(7,9)$.

This study aims to investigate the adulteration of 20 PDE-5 inhibitors and analogues in 55 herbal products of various preparations (powder, tablets, capsules, and pastels) from the Malaysian market, between the duration of $1^{\text {st }}$ January 2016 and $11^{\text {th }}$ October 2017 received by the Malaysia National Poison Centre (NPC). Gas chromatograph-electron impact-mass spectrometer (GC-EI-MS) was used to screen and identify these PDE-5 drugs and analogues. The potential use of GC-EI-MS for quantification assay was further confirmed by using ten randomly selected PDE-5 inhibitors and their analogues.

\section{Materials and Methods:}

All certified PDE-5 inhibitors were purchased from TLC PharmChem, Canada: Acetylvardenafil, (98.6\%), Acetildenafil, (99.8\%), Aminotadalafil (99.9\%), Carbodenafil (99.0\%), Desmethylcarbodenafil (99.7\%), Dimethylsildenafil (99.9\%), Gendenafil (98.9\%), Homosildenafil (99.6\%), $\quad \mathrm{N}$-octyl-nortadalafil $\quad(99.5 \%)$, Norneosildenafil (99.7\%), Nortadalafil (100\%), $\mathrm{N}$ desmethylsildenafil (99.9\%), Piperiacetildenafil (99.1\%), Pseudovardenafil (99.8\%), Sildenafil (99.8\%), Tadalafil (100.0\%), Thiosildenafil (98.9\%), Thiohomosildenafil (100.0\%), Thiodimethylsildenafil (99.9\%), Vardenafil (99.5\%) and $d^{8}$-sildenafil $(99.7 \%)$. Other chemicals were

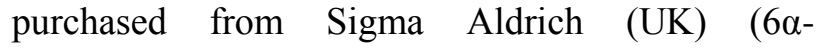
Methylprednisolone), Fischer Scientific (UK) (methanol) and James Burrough, FAD-UK (ethanol).

\section{Standard and sample preparations Screening, and identification}

Stock solutions containing $1.0 \mathrm{mg} / \mathrm{mL}$ of 20 PDE-5 drugs and their analogues, standard solutions $(0.1 \mathrm{mg} / \mathrm{ml})$, mixture of the drugs $(40.0$ $\mu \mathrm{g} / \mathrm{mL}$ ), internal standard (IS), $d^{8}$-sildenafil (50 $\mu \mathrm{g} / \mathrm{ml})$, and external standard (ES), $6 \alpha-$ methylprednisolone $(0.25 \mathrm{mg} / \mathrm{ml})$ were prepared in methanol. Samples of $0.1 \mathrm{~g}$ were dissolved in $0.5 \mathrm{~mL}$ methanol through $7 \mathrm{~min}$ sonication, followed by 4 min vortex and 3 min centrifugation at $1000 \mathrm{rpm}$. A volume of $0.25 \mathrm{~mL}$ supernatant was added with $25 \mu \mathrm{L}$ IS and dried over nitrogen gas flow at $40{ }^{\circ} \mathrm{C}$. The dried extract was reconstituted with $50 \mu \mathrm{L}$ of ES before GC-EI-MS analysis. Validation samples $(20 \mu \mathrm{g} / \mathrm{g})$, each consisting 10 different tablets, capsules, pastels and powdered herbs were prepared by spiking $2 \mu \mathrm{g}$ drugs in each $0.1 \mathrm{~g}$ blank herbs and subjected to above preparations. Blank herb matrices were tested according to the procedure, and found negative before being spiked and treated as validation samples.

\section{Quantification}

Standard mixtures containing $0.001,0.010$ and $0.100 \mathrm{mg} / \mathrm{mL}$ of sildenafil, vardenafil, gendenafil, norneosildenafil, pseudovardenafil, thiosildenafil, thiodimethylsildenafil, acetildenafil, piperiacetildenafil and nortadalafil were prepared in ethanol. They were used in the daily preparation of the calibration curves from to $1-40 \mu \mathrm{g} / \mathrm{mL}$ or equivalent to $5-200 \mu \mathrm{g} / \mathrm{g}$ drugs.

Weight of powdered herb sample or validation sample $(0.05 \mathrm{~g})$ was added with $25 \mu \mathrm{L}$ IS and mixed in $0.25 \mathrm{~mL}$ ethanol through $7 \mathrm{~min}$ sonication, followed by $4 \mathrm{~min}$ vortex and $3 \mathrm{~min}$ centrifugation at $1000 \mathrm{rpm}$. A total of 15 validation samples at concentration $1 \mu \mathrm{g} / \mathrm{mL}$ or $5 \mu \mathrm{g} / \mathrm{g}(\mathrm{n}=5)$, $10 \mu \mathrm{g} / \mathrm{mL}$ or $50 \mu \mathrm{g} / \mathrm{g}(\mathrm{n}=5)$ and $40 \mu \mathrm{g} / \mathrm{mL}$ or 200 $\mu \mathrm{g} / \mathrm{g}(\mathrm{n}=5)$ were prepared daily in blank herbs. The analysis was carried out for three different days.

\section{GC-EI-MS conditions}

The GC-EI-MS system consists of HP6890 GC, HP5973 MS (Agilent Technologies) and fused silica capillary column, HP-5MS $(15 \mathrm{~m} \times 0.25 \mathrm{~mm}$ i.d. $0.25 \mu \mathrm{m}$ film thickness). A $1 \mu \mathrm{L}$ injection using splitless mode was performed on $300{ }^{\circ} \mathrm{C}$ injector port. The carrier gas was helium at a flow rate of $2.1 \mathrm{~mL} / \mathrm{min}$. The MS interface, ion source and quadrupole temperatures were set at $280{ }^{\circ} \mathrm{C}, 230{ }^{\circ} \mathrm{C}$ and $150{ }^{\circ} \mathrm{C}$, respectively. The electron ionisation was performed at $70 \mathrm{eV}$ with full scan mode at 30$800 \mathrm{amu}$. The oven ramping temperature was programmed with the initial temperature at $150{ }^{\circ} \mathrm{C}$, raised at $25{ }^{\circ} \mathrm{C} / \mathrm{min}$ to $290{ }^{\circ} \mathrm{C}$ and raised again at 5 ${ }^{\circ} \mathrm{C} / \mathrm{min}$ to $320{ }^{\circ} \mathrm{C}$ and held for $4.4 \mathrm{~min}$. For quantification, the initial oven temperature was set at $100{ }^{\circ} \mathrm{C}$, raised at $25^{\circ} \mathrm{C} / \mathrm{min}$ to $320{ }^{\circ} \mathrm{C}$ (held for 15 $\min )$. 


\section{Results and Discussion:}

A total of 55 herbal samples were screened for PDE-5 inhibitors and analogues. Analysis has shown that 19 samples were found to be positive for sildenafil $(\mathrm{n}=7)$, tadalafil $(\mathrm{n}=6)$, aminotadalafil $(n=1), \quad$ desmethylcarbodenafil $\quad(n=1)$, thiodimethylsildenafil $(\mathrm{n}=1)$ and mixtures of sildenafil with either tadalafil $(n=2)$ or aminotadalafil $(n=1)$. Currently, the number of PDE-5 inhibitors and analogues reported in the literature has reached 61 (5). For cost-effective purposes, only 20 PDE-5 inhibitors and analogues were chosen for identification, and they are within the capability of detection by GC-EI-MS.

This study found that ethanol was a better solvent than methanol and isopropanol for the extraction of PDE-5 inhibitors and analogues from herbal matrices. However, recovery of analogues was found to be higher by using lower chain alcohol (methanol>ethanol>isopropanol). Therefore, methanol was chosen as a solvent for screening, while ethanol was employed for quantification. Using each of the $100 \mu \mathrm{g} / \mathrm{mL}$ standard solutions of PDE-5 inhibitors and analogues, the GC-EI-MS spectra were produced and added to our database for screening and identification purposes. The MS fragmentations for 20 PDE-5 inhibitors and analogues are shown in Table 1. The molecular ions of the studied compounds remained intact in all of the drugs. Some existed as base ions, thus facilitating the identification process. The GC-EIMS assay is capable of screening all 20 drugs with good chromatographic separation within $15 \mathrm{~min}$, as shown by the retention index (RI) and retention time (RT) in Table 1. ES was used in order to monitor the RT shift due to the presence of endogenous substances in herbs.

The chemical structures of sildenafil, vardenafil and their analogues consist of three main moieties i.e. alkyl piperazine, sulfonyl and alkoxypyrazolopyrimidine (sildenafil) or alkoxyimidazolotriazine (vardenafil) (Fig.1).

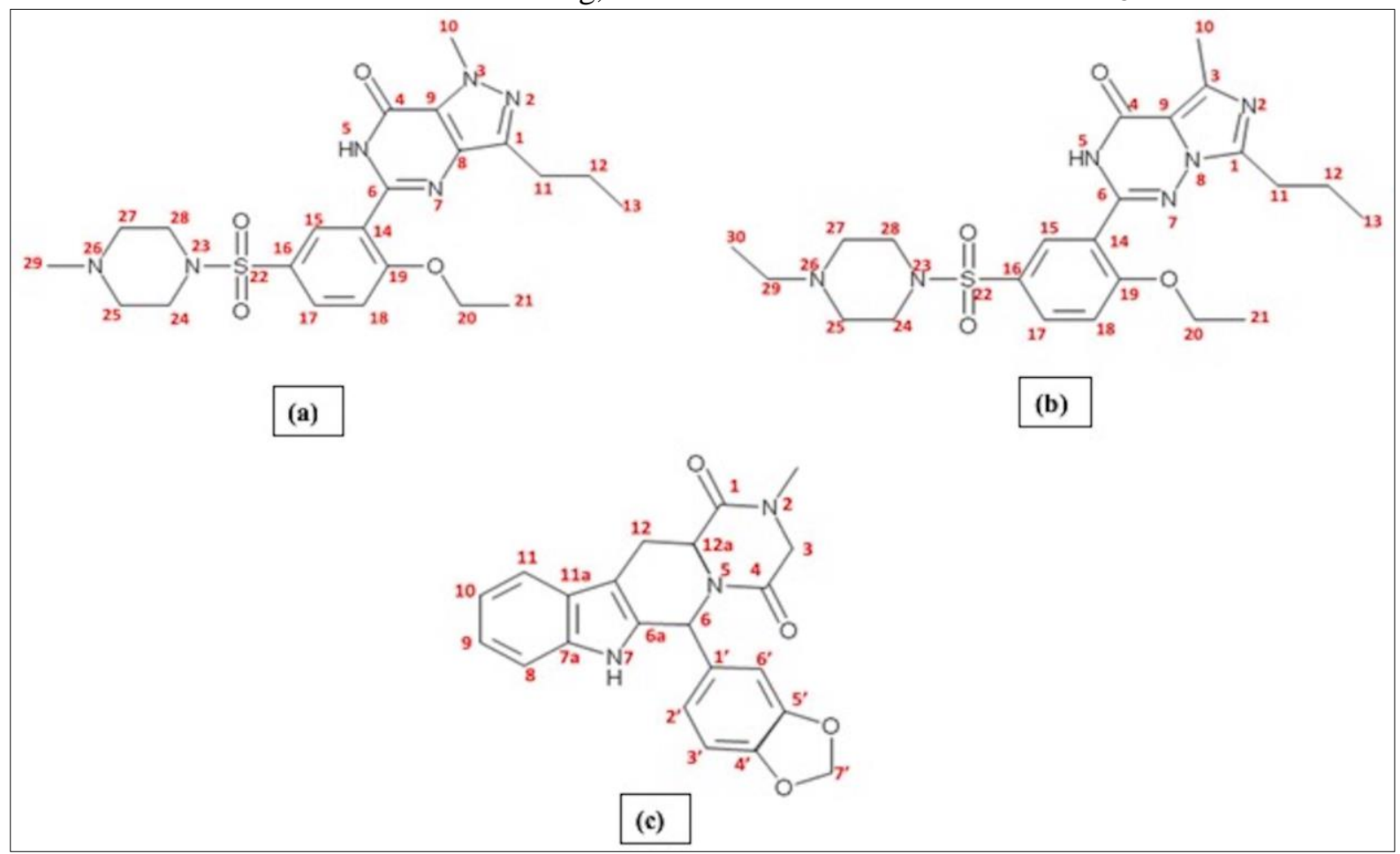

Figure 1. Structures of: (a) Sildenafil (b) Vardenafil and (c) Tadalafil

Among PDE-5 inhibitors, analogue tadalafil is known to have stereoisomers which are identified using chiral LC column (10). In this developed GCEI-MS assay, chromatographic separation of the high purity of tadalafil, aminotadalafil and $n$-octylnortadalafil produced two adjacent peaks with similar mass spectrum (Table 1). These stereoisomers were probably derived from GC high injection temperature. The tadalafil analogues contain functional groups; alkyl and amino bonded at $\mathrm{N}-2$ position in piperazinedione ring. No isomer peak was seen for nortadalafil which has no functional group at N-2 position in piperazinedione ring. Tadalafil and its analogues exhibited unique MS fragmentations with high intensity (base ion) of the molecular ions and subsequent loss of benzodioxole ring $(-m / z, 121)$. Other characteristic ions are shown in Table 1. MS fragmentation for other analogues was also described in Table 1.

In quantitation analysis, the limit of detection (LOD) of each drug was found to be between $0.1-1.0 \mu \mathrm{g} / \mathrm{g}$ except for aminotadalafil (4.7 
$\mu \mathrm{g} / \mathrm{g})$ and $N$-desmethylsildenafil $(1.6 \mu \mathrm{g} / \mathrm{g})$ in 10 different herbal preparations of powder, capsules, tablets and pastels. Generally, the sensitivity achieved for sildenafil and vardenafil were better than the previously reported GC-MS data (11). Currently, the doses for the intended pharmacological effect are only available for sildenafil $(25-100 \mathrm{mg})$, tadalafil $(10-20 \mathrm{mg})$ and vardenafil $(5-20 \mathrm{mg})$ (12). To the best of our knowledge, no recommended dose is available for the analogues since they are banned substances and their pharmacokinetic effect and safety profile have yet to be determined. For the estimated maximum amount of serving size, $0.3 \mathrm{~g}$ (pills, tablets, capsules, pastels) and $20 \mathrm{~g}$ powdered herb samples; it may contain at least $1.25-83.33 \mathrm{mg} / \mathrm{g}$ sildenafil, $0.50-33.33 \mathrm{mg} / \mathrm{g}$ tadalafil and $0.25-16.67 \mathrm{mg} / \mathrm{g}$ vardenafil. The current developed GC-EI-MS assay has very low LODs $(0.0001-0.0050 \mathrm{mg} / \mathrm{g})$. Hence, the assay has sufficient sensitivity to screen PDE-5 inhibitors and their analogues in herbal matrices for adulteration screening.

Table 1. Retention time, retention index and mass fragmentations of the PDE-5 enzyme inhibitors and analogues analysed by GC-EI-MS

\begin{tabular}{|c|c|c|c|c|c|c|c|}
\hline No & Drugs & $\begin{array}{l}\text { Chemical } \\
\text { Formulae }\end{array}$ & $\begin{array}{c}\text { Retention } \\
\text { Index } \pm 30\end{array}$ & $\begin{array}{c}\mathrm{RT} \pm \\
0.5 \\
\min \\
\end{array}$ & $\begin{array}{c}\text { M+ } \\
(m / z)\end{array}$ & $\begin{array}{c}\text { Base } \\
\text { ion } \\
(\mathrm{m} / \mathrm{z}) \\
\end{array}$ & Other major ions $(\mathrm{m} / \mathrm{z})$ \\
\hline 1 & Gendenafil & $\mathrm{C}_{19} \mathrm{H}_{22} \mathrm{~N}_{4} \mathrm{O}_{3}$ & 3096 & 5.66 & $\begin{array}{c}354 \\
(100 \%)\end{array}$ & 354 & $\begin{array}{c}339(47 \%), 336(7 \%), 326(79 \%), \\
321(22 \%), 312(4 \%), 311(18 \%), \\
297(15 \%), 283(19 \%), 282(27 \%), \\
193(11 \%), 166(28 \%), 162(6 \%), \\
136(46 \%), 43(16 \%)\end{array}$ \\
\hline 2 & Piperiacetildenafil & $\mathrm{C}_{24} \mathrm{H}_{31} \mathrm{~N}_{5} \mathrm{O}_{3}$ & 3661 & 7.77 & $\begin{array}{c}437 \\
(1 \%)\end{array}$ & 98 & $\begin{array}{c}312(1 \%), 311(2 \%), 297(1 \%) \\
283(1 \%), 282(1 \%), 166(1 \%) \\
136(2 \%), 70(3 \%), 55(4 \%), 42 \\
(4 \%), 30(1 \%)\end{array}$ \\
\hline 3 & Desmethylcarbodenafil & $\mathrm{C}_{23} \mathrm{H}_{30} \mathrm{~N}_{6} \mathrm{O}_{3}$ & 3847 & 8.75 & $\begin{array}{c}438 \\
(10 \%)\end{array}$ & 70 & $\begin{array}{c}400(2 \%), 381(7 \%), 368(7 \%), \\
355(6 \%), 339(7 \%), 312(1 \%), \\
311(6 \%), 283(1 \%), 282(1 \%), \\
166(3 \%), 136(3 \%), 99(15 \%), 83 \\
(29 \%), 56(21 \%), 43(10 \%), 30 \\
(2 \%)\end{array}$ \\
\hline 4 & Tadalafil & $\mathrm{C}_{22} \mathrm{H}_{19} \mathrm{~N}_{3} \mathrm{O}_{4}$ & $\begin{array}{l}3838 \\
3882\end{array}$ & $\begin{array}{c}8.7 \\
8.96\end{array}$ & $\begin{array}{c}389 \\
(100 \%)\end{array}$ & 389 & $\begin{array}{c}318(5 \%), 317(8 \%), 289(12 \%), \\
275(6 \%), 268(20 \%), 263(45 \%), \\
262(68 \%), 254(2 \%), 233(20 \%), \\
204(33 \%), 169(21 \%), 115(8 \%), \\
102(12 \%), 44(7 \%)\end{array}$ \\
\hline 5 & Acetildenafil & $\mathrm{C}_{25} \mathrm{H}_{34} \mathrm{~N}_{6} \mathrm{O}_{3}$ & 3826 & 8.63 & $\begin{array}{c}466 \\
(4 \%)\end{array}$ & 127 & $\begin{array}{c}312(1 \%), 311(1 \%), 283(1 \%), \\
282(0.6 \%), 166(1 \%), 136(2 \%), \\
112(4 \%), 98(3 \%), 84(16 \%), 70 \\
(17 \%), 56(6 \%), 42(7 \%), 30(1 \%)\end{array}$ \\
\hline 6 & Acetylvardenafil & $\mathrm{C}_{25} \mathrm{H}_{34} \mathrm{~N}_{6} \mathrm{O}_{3}$ & 3859 & 8.83 & $\begin{array}{c}466 \\
(3 \%)\end{array}$ & 127 & $\begin{array}{c}326(1 \%), 312(1 \%), 311(1 \%), \\
283(1 \%), 282(1 \%), 133(1 \%), \\
112(2 \%), 98(3 \%), 84(14 \%), 70 \\
(15 \%), 56(4 \%), 42(6 \%)\end{array}$ \\
\hline 7 & Carbodenafil & $\mathrm{C}_{24} \mathrm{H}_{32} \mathrm{~N}_{6} \mathrm{O}_{3}$ & 3882 & 9.07 & $\begin{array}{c}452 \\
(9 \%)\end{array}$ & 84 & $\begin{array}{c}381(10 \%), 339(9 \%), 312(3 \%), \\
311(8 \%), 283(1 \%), 282(1 \%), \\
281(2 \%), 166(3 \%), 136(4 \%), \\
113(8 \%), 97(21 \%), 70(13 \%), 56 \\
(14 \%), 42(10 \%), 30(1 \%)\end{array}$ \\
\hline 8 & Pseudovardenafil & $\mathrm{C}_{22} \mathrm{H}_{29} \mathrm{~N}_{5} \mathrm{O}_{4} \mathrm{~S}$ & 3931 & 9.26 & $\begin{array}{c}459 \\
(54 \%)\end{array}$ & 431 & $\begin{array}{c}444(14 \%), 416(3 \%), 312(4 \%), \\
311(5 \%), 296(3 \%), 284(15 \%), \\
283(15 \%), 282(10 \%), 254(5 \%), \\
215(5 \%), 166(3 \%), 136(2 \%), \\
135(6 \%), 94(7 \%), 84(14 \%), 67 \\
(17 \%), 55(11 \%), 42(18 \%), 30 \\
(2 \%)\end{array}$ \\
\hline 9 & Aminotadalafil & $\mathrm{C}_{21} \mathrm{H}_{18} \mathrm{~N}_{4} \mathrm{O}_{4}$ & $\begin{array}{l}3950 \\
3975\end{array}$ & $\begin{array}{l}9.38 \\
9.53\end{array}$ & $\begin{array}{c}390 \\
(100 \%)\end{array}$ & 390 & $\begin{array}{c}374(14 \%), 331(8 \%), 318(11 \%), \\
317(9 \%), 289(38 \%), 274(5 \%), \\
269(10 \%), 263(33 \%), 262(51 \%), \\
252(4 \%), 233(17 \%), 204(36 \%), \\
169(18 \%), 115(12 \%), 102 \\
(12 \%), 44(4 \%)\end{array}$ \\
\hline 10 & Sildenafil & $\mathrm{C}_{22} \mathrm{H}_{30} \mathrm{~N}_{6} \mathrm{O}_{4} \mathrm{~S}$ & 3955 & 9.41 & $\begin{array}{c}474 \\
(1 \%)\end{array}$ & 99 & $\begin{array}{c}404(33 \%), 312(3 \%), 311(3 \%), \\
283(3 \%), 282(1 \%), 254(1 \%), \\
166(1 \%), 136(2 \%), 84(1 \%), 70\end{array}$ \\
\hline
\end{tabular}




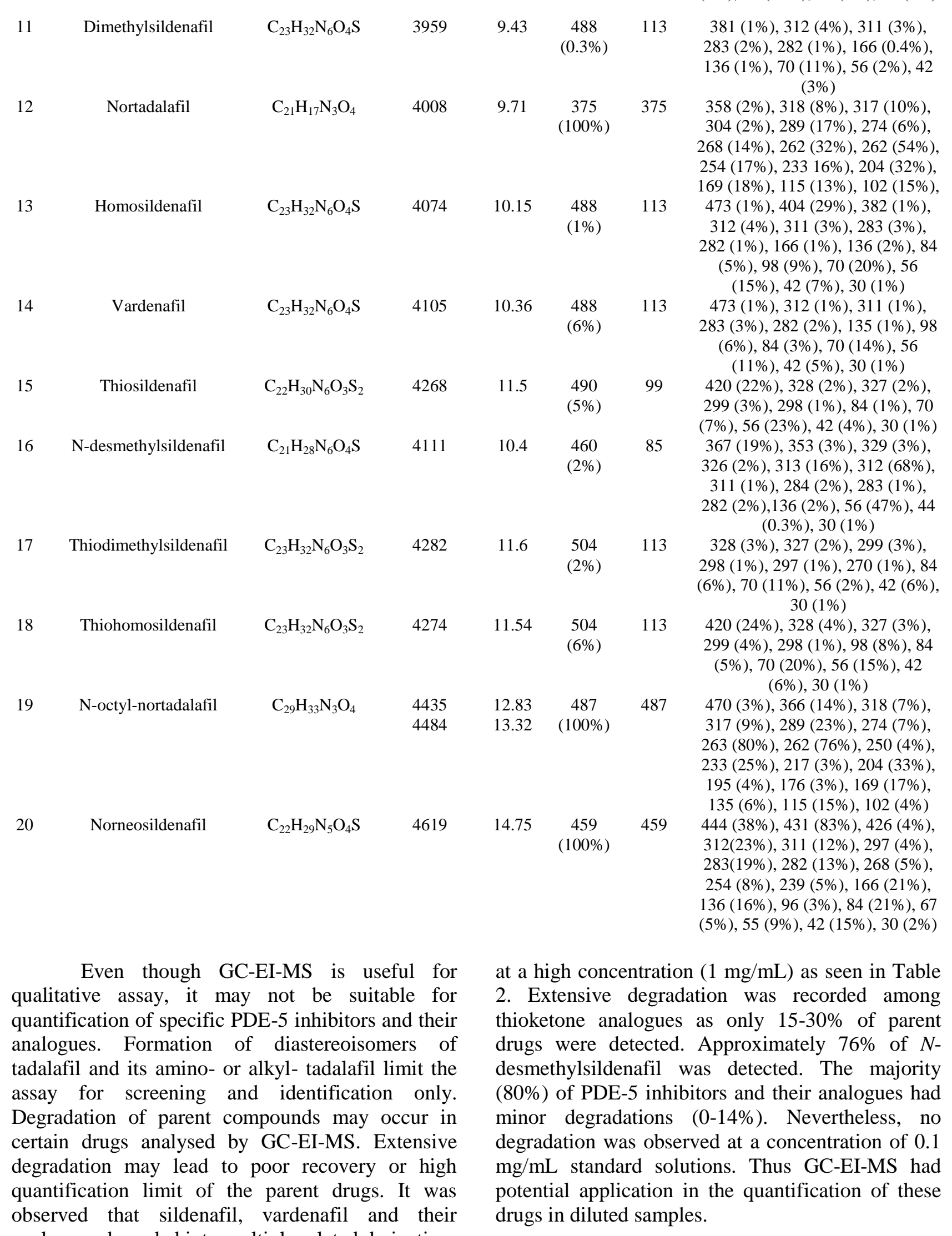
analogues degraded into multiple related derivatives 
Table 2. Percent composition of parent and degradation/ related products of PDE-5 enzyme inhibitors and analogues analysed by GC-EI-MS (based on total ion chromatogram)

\begin{tabular}{ccccccccc} 
& \% & \multicolumn{2}{c}{ Peak 2 } & \multicolumn{2}{c}{ Peak 3 } & \multicolumn{2}{c}{ Peak 4 } & Others \\
Drugs & $\begin{array}{c}\text { Peak 1 } \\
\text { (Parent) }\end{array}$ & RT & \% & RT & \% & RT & \% & No. of peaks-\% \\
\hline Gendenafil & 100.0 & & & & & & & \\
Piperiacetildenafil & 92.0 & 11.73 & 4.2 & 5.69 & 1.6 & 5.77 & 0.6 & 3 peaks- $1.6 \%$ \\
Desmethylcarbodenafil & 97.6 & 9.44 & 1.7 & 7.34 & 0.7 & - & - & - \\
Tadalafil & 99.4 & 10.03 & 0.6 & - & - & - & - & - \\
Acetildenafil & 85.9 & 9.57 & 6.4 & 5.71 & 3.1 & 5.96 & 1.7 & 5 peaks- $2.9 \%$ \\
Acetylvardenafil & 94.5 & 5.83 & 3.7 & 7.70 & 1.4 & 5.03 & 0.4 & - \\
Carbodenafil & 98.3 & 8.20 & 1.2 & 10.7 & 0.5 & - & - & - \\
Pseudovardenafil & 87.8 & 8.56 & 10.8 & 8.73 & 1.4 & - & - & - \\
Aminotadalafil & 100.0 & - & - & - & - & - & - & - \\
Sildenafil & 92.2 & 10.94 & 3.2 & 8.55 & 2.0 & 8.83 & 1.3 & 2 peaks- $1.3 \%$ \\
Dimethylsildenafil & 87.2 & 10.37 & 4.1 & 10.85 & 2.9 & 11.23 & 2.6 & 3 peaks- $3.2 \%$ \\
Nortadalafil & 100.0 & - & - & - & - & - & - & - \\
Homosildenafil & 91.2 & 8.99 & 4.3 & 11.83 & 2.0 & 9.8 & 1.1 & 2 peaks $-0.6 \%$ \\
Vardenafil & 97.1 & 8.81 & 2.2 & 4.71 & 0.7 & - & - & - \\
Thiosildenafil & 15.0 & 10.89 & 46.4 & 11.91 & 20.6 & 12.03 & 10.6 & 5 peaks- $7.4 \%$ \\
N-desmethylsildenafil & 75.5 & 4.77 & 8.0 & 10.36 & 8.7 & 9.0 & 4.3 & 2 peaks $-3.5 \%$ \\
Thiodimethylsildenafil & 29.5 & 10.24 & 32.9 & 11.33 & 31.5 & 12.03 & 1.3 & 6 peaks- $4.8 \%$ \\
Thiohomosildenafil & 19.3 & 12.01 & 45.0 & 10.80 & 35.1 & 5.12 & 0.3 & 2 peaks $-0.3 \%$ \\
N-octyl-nortadalafil & 99.0 & 14.90 & 1.0 & - & - & - & - & - \\
\hline
\end{tabular}

$\mathrm{RT}=$ retention time $(\mathrm{min})$

Validation was successfully performed using ten randomly selected PDE-5 inhibitors and analogues as shown in Table 3. Calibration curves for acetildenafil, piperiacetildenafil and nortadalafil were plotted from 10 to $40 \mu \mathrm{g} / \mathrm{mL}$ (or 50 to 200 $\mu \mathrm{g} / \mathrm{g})$. The calibration range for other drugs was plotted from a lower point, i.e. $1 \mu \mathrm{g} / \mathrm{mL}$ or $5 \mu \mathrm{g} / \mathrm{g}$. The calibration curves were linear with an average correlation coefficient, $\mathrm{R}^{2} \geq 0.996$ (Table 3 ). The within- and between-assays precision and accuracy of all drugs are within the acceptable range with an excellent recovery at 91.28-118.85\%. This data proved that PDE-5 inhibitors and analogues could be quantified in herbal preparations by GC-EI-MS. More than $85 \%$ thioketone analogues (thiosildenafil and thiodimethylsildenafil) was recovered at a concentration of $5 \mu \mathrm{g} / \mathrm{g}$. However, low recovery (49-61\%) was recorded at higher concentrations which may be due to the degradation in matrices and the use of a weak organic solvent (ethanol). Nevertheless, a study had reported a recovery of $\geq$ $73.6 \%$ for 38 PDE-5 inhibitors and analogues using LC-MS/MS assay (12). Limit of quantitation for the assay was $1 \mu \mathrm{g} / \mathrm{mL}$ or $5 \mu \mathrm{g} / \mathrm{g}$ for all drugs except acetildenafil, piperiacetildenafil and nortadalafil (10 $\mu \mathrm{g} / \mathrm{g})$.

The validated GC-EI-MS assay was successfully tested on real samples, qualitatively and quantitatively. However, GC-EI-MS may not be able to replace or provide for an alternative technique to other more superior techniques such as LC-MS $(13,14)$ and LC-MS/MS $(15,16)$, its simplicity, sensitivity, selectivity and economical are sufficient for compound identification and as a complementary technique to support the findings of other conventional methods such as HPLC (15), ELISA (17) and thin-layer chromatography (18).

A Malaysian study conducted between 2014-2016 which screened 61 PDE-5 inhibitors and analogues showed that $82 \%$ of unregistered herbal and food products were adulterated with at least one PDE-5 inhibitor or analogue (5). In this study, 35\% of herbal products which were dispatched to the NPC from 2016 to 2017 were proven to contain at least one PDE-5 inhibitor or analogue. Even though the percentage of adulteration is lower, it should be highlighted that the current study focused only on herbal products with a screening of 20 PDE-5 inhibitors and analogues. 
Table 3. The within assay, between assay precisions and accuracies and recovery of spiked 1, 10, 40 $\mu \mathrm{g} / \mathrm{mL}$ (or 5, 50, $200 \mu \mathrm{g} / \mathrm{g}$ ) PDE-5 inhibitors and analogues analysed by GC-EI-MS

\begin{tabular}{|c|c|c|c|c|c|c|c|c|c|c|}
\hline \multirow[b]{2}{*}{ Analyte } & \multirow[b]{2}{*}{ 昰苞 } & \multirow[b]{2}{*}{$\mathbf{R}^{2}$} & \multirow[b]{2}{*}{ 焉㐭 } & \multirow{2}{*}{ 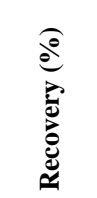 } & \multicolumn{3}{|c|}{ Within-assay $^{\mathbf{a}}$} & \multicolumn{3}{|c|}{ Between-assay $^{b}$} \\
\hline & & & & & $\begin{array}{c}\text { Observed } \\
(\mathrm{mean} \pm \mathrm{SD}) \\
(\mu \mathrm{g} / \mathrm{mL})\end{array}$ & 氖 & 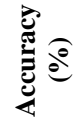 & $\begin{array}{c}\text { Observed } \\
(\text { mean } \pm \text { SD }) \\
(\mu \mathrm{g} / \mathrm{mL})\end{array}$ & $\begin{array}{c}\text { Precisi } \\
\text { on } \\
(\%)\end{array}$ & $\begin{array}{c}\text { Accura } \\
\text { cy } \\
(\%)\end{array}$ \\
\hline \multirow{3}{*}{ Gendenafil } & \multirow{3}{*}{$1-40$} & \multirow{3}{*}{0.998} & 1 & 118.85 & $1.034 \pm 0.071$ & 6.83 & 3.38 & $1.086 \pm 0.045$ & 8.32 & 8.57 \\
\hline & & & 10 & 105.04 & $9.022 \pm 1.136$ & 12.57 & 9.78 & $9.320 \pm 0.635$ & 11.19 & 7.13 \\
\hline & & & 40 & 92.23 & $40.748 \pm 5.625$ & 13.80 & 1.87 & $40.728 \pm 3.248$ & 8.12 & 7.08 \\
\hline \multirow[t]{2}{*}{ Piperiacetildenafil } & \multirow[t]{2}{*}{$10-40$} & \multirow[t]{2}{*}{0.998} & 10 & 109.52 & $8.563 \pm 1.111$ & 12.98 & 14.37 & $9.206 \pm 0.561$ & 6.09 & 7.94 \\
\hline & & & 40 & 92.14 & $37.110 \pm 4.764$ & 12.80 & 7.20 & $39.116 \pm 2.747$ & 7.02 & 5.95 \\
\hline \multirow[t]{3}{*}{ Acetildenafil } & \multirow[t]{3}{*}{$10-40$} & \multirow[t]{3}{*}{0.997} & 10 & 92.77 & $10.367 \pm 1.070$ & 10.32 & 3.67 & $10.337 \pm 1.270$ & 12.31 & 4.95 \\
\hline & & & 40 & 91.28 & $38.921 \pm 5.416$ & 13.92 & 2.70 & $38.333 \pm 3.418$ & 9.02 & 7.08 \\
\hline & & & 1 & 92.18 & $1.115 \pm 0.130$ & 11.68 & 11.46 & $0.988 \pm 0.116$ & 13.20 & 8.84 \\
\hline \multirow[t]{3}{*}{ Norneosildenafil } & \multirow[t]{3}{*}{$1-40$} & \multirow[t]{3}{*}{0.997} & 10 & 98.35 & $10.105 \pm 0.876$ & 8.67 & 1.05 & $9.777 \pm 0.350$ & 7.65 & 2.93 \\
\hline & & & 40 & 102.18 & $39.763 \pm 2.150$ & 5.41 & 0.59 & $40.185 \pm 0.368$ & 7.53 & 0.86 \\
\hline & & & 1 & 111.73 & $1.054 \pm 0.011$ & 1.03 & 5.46 & $1.050 \pm 0.060$ & 5.75 & 9.29 \\
\hline \multirow[t]{3}{*}{ Pseudovardenafil } & \multirow[t]{3}{*}{$1-40$} & \multirow[t]{3}{*}{0.999} & 10 & 91.95 & $10.173 \pm 0.938$ & 9.23 & 1.73 & $10.054 \pm 0.726$ & 7.15 & 2.76 \\
\hline & & & 40 & 96.39 & $38.413 \pm 2.877$ & 7.49 & 3.97 & $39.236 \pm 3.282$ & 8.36 & 1.91 \\
\hline & & & 1 & 99.1 & $1.059 \pm 0.093$ & 8.75 & 5.95 & $1.022 \pm 0.036$ & 9.20 & 3.04 \\
\hline \multirow[t]{2}{*}{ Sildenafil } & \multirow[t]{2}{*}{$1-40$} & \multirow[t]{2}{*}{0.996} & 10 & 103.63 & $9.702 \pm 0.970$ & 10.00 & 2.98 & $10.287 \pm 0.579$ & 6.57 & 4.86 \\
\hline & & & 40 & 99.47 & $39.579 \pm 2.148$ & 5.43 & 1.05 & $39.345 \pm 0.941$ & 5.18 & 1.64 \\
\hline \multirow[t]{3}{*}{ Nortadalafil } & \multirow[t]{3}{*}{$10-40$} & \multirow[t]{3}{*}{0.997} & 10 & 114.06 & $8.846 \pm 0.839$ & 9.48 & 11.54 & $9.311 \pm 0.410$ & 4.41 & 6.87 \\
\hline & & & 40 & 96.54 & $38.228 \pm 3.610$ & 9.44 & 4.43 & $38.564 \pm 0.408$ & 1.06 & 3.59 \\
\hline & & & 1 & 110.53 & $1.009 \pm 0.063$ & 6.21 & 0.89 & $1.100 \pm 0.080$ & 8.55 & 10.02 \\
\hline \multirow[t]{2}{*}{ Vardenafil } & $1-10$ & 0.998 & 10 & 105.60 & $10.002 \pm 0.808$ & 8.08 & 0.02 & $10.035 \pm 1.037$ & 9.74 & 0.35 \\
\hline & & & 40 & 103.99 & $40.112 \pm 1.124$ & 2.80 & 0.28 & $38.192 \pm 2.516$ & 6.57 & 4.52 \\
\hline & & & 1 & 87.12 & $1.121 \pm 0.110$ & 9.82 & 12.12 & $1.061 \pm 0.139$ & 14.95 & 12.64 \\
\hline Ihiosildenatil & $1-40$ & 0.999 & 10 & 76.45 & $8.526 \pm 1.166$ & 13.67 & 14.74 & $8.926 \pm 0.914$ & 12.57 & 10.74 \\
\hline & & & 40 & 61.20 & $37.201 \pm 3.914$ & 10.52 & 7.00 & $40.159 \pm 3.190$ & 8.00 & 5.50 \\
\hline & & & 1 & 86.10 & $1.028 \pm 0.067$ & 6.51 & 2.78 & $1.048 \pm 0.076$ & 11.73 & 4.80 \\
\hline Thiodimethylsilde & $1-40$ & 0.998 & 10 & 66.70 & $8.850 \pm 1.174$ & 13.26 & 11.50 & $9.064 \pm 0.340$ & 10.41 & 9.36 \\
\hline & & & 40 & 48.69 & $35.634 \pm 4.458$ & 12.51 & 10.91 & $36.934 \pm 1.802$ & 8.57 & 7.67 \\
\hline
\end{tabular}

$\mathrm{a}=5$ replicates, $\mathrm{b}=15$ replicates

\section{Conclusion:}

GC-EI-MS assay was successfully developed and tested on real samples, qualitatively and quantitatively, and it has been proven to be simple, sensitive, selective and economical for the screening and identification of PDE-5 inhibitors and their analogues. From 55 samples received by the NPC between $1^{\text {st }}$ January 2016 and $11^{\text {th }}$ October 2017, 19 samples were found to be adulterated with at least one PDE-5 inhibitor or analogue. Effective strategy must be employed to reduce the alarming increase of adulteration of PDE-5 inhibitors and analogues in Malaysian herbal products, through regular monitoring and surveillance, thus ensuring product quality and safety. In addition, the public should be educated and informed about the risks of using adulterated and tainted products which are claimed to be safe and "natural".

\section{Authors' declaration:}

- Conflicts of Interest: None.

- We hereby confirm that all Figures and Tables in the manuscript belonged to the authors. Figures and images, which did not belong to the authors, have been given the permission for republication attached with the manuscript.

- Ethical Clearance: The project was approved by the local ethical committee in Universiti Sains Malaysia.

\section{References:}

1. Damiano F, Silva C, Gregori A, Vacondio F, Mor M, Menozzi M, et al. Analysis of illicit dietary supplements sold in the Italian market: Identification of a sildenafil thio-derivative as adulterant using UPLC-TOF/MS and GC/MS. Sci Justice. 2014;54:228-37.

2. Vaclavik L, Krynitsky AJ, Rader JI. Mass spectrometric analysis of pharmaceutical adulterants in products labelled as botanical dietary supplements or herbal remedies: A review. Anal Bioanal Chem. 2014;406:6767-90.

3. ElAgouri G, AlAmrawy F, ElYazbi A, Eshra A, Nounou MI. Male enhancement nutraceuticals in the middle east market: Claim, pharmaceutical quality and safety assessments. Int J Pharm. 2015 Aug; 492:109-19.

4. Rocha T, Amaral JS, Oliveira MBPP. Adulteration of dietary supplements by the illegal addition of synthetic drugs: A review. Compr Rev Food Sci Food Saf. 2015;15:43-62. 
5. Bujang NB, Chee CF, Heh CH, Rahman NA, Buckle MJC. Phosphodiesterase-5 inhibitors and their analogues as adulterants of herbal and food products: analysis of the Malaysian market, 2014-16. Food Addit Contam Part A Chem Anal Control Expo Risk Assess. 2017; 34(7):1101-9.

6. Viigimaa M, Vlachopoulos C, Lazaridis A, Doumas M. Management of erectile dysfunction in hypertension: Tips and tricks. World J Cardiol. 2014 ; 6(9):908-15.

7. Campbell N, Clark JP, Stecher VJ, Thomas JW, Callanan AC, Donnelly BF, et al. Adulteration of purported herbal and natural sexual performance enhancement dietary supplements with synthetic phosphodiesterase type-5 inhibitors. J Sex Med. 2015;10:1842-9.

8. Lin YT, Huang YC, Lee HC, Liao CH, Lin YL, Tsai $\mathrm{CF}$, et al. Isolation and identification of a novel sildenafil analogue adulterant in herbal products. Food Addit Contam Part A Chem Anal Control Expo Risk Assess. 2017;34(3):330-4.

9. Huang Y-C, Lee H-C, Lin Y-L, Lin Y-T, Tsai C-F, Cheng H-F. Identification of a new sildenafil analogue adulterant, desethylcarbodenafil, in a herbal supplement. Food Addit Contam Part A Chem Anal Control Expo Risk Assess. 2016;33(11)1637-42.

10. Ulloa J, Sambrotta L, Redko F, Mazza ON, Garrido $\mathrm{G}$, Becher EF, et al. Detection of a tadalafil analogue as an adulterant in a dietary supplement for erectile dysfunction. J Sex Med. 2015;12:152-7.

11. Balayssac S, Gilard V, Zedde C, Martino R, MaletMartino M. Analysis of herbal dietary supplements for sexual performance enhancement: First characterisation of propoxyphenylthiohydroxyhomosildenafil and identification of sildenafil, thiosildenafil, phentolamine and tetrahydropalmatine as adulterants. J Pharm Biomed Anal. 2012; 63:135-50.

12. Lee ES, Lee JH, Han KM, Kim JW, Hwang IS, Cho $\mathrm{S}$, et al. Simultaneous determination of 38 phosphodiesterase-5 inhibitors in illicit erectile dysfunction products by liquid chromatographyelectrospray ionisation-tandem mass spectrometry. J Pharm Biomed Anal. 2013; 83:171-8.

13. Lin YT, Huang YC, Lee HC, Liao CH, Lin YL, Tsai $\mathrm{CF}$, et al. Isolation and identification of a novel sildenafil analogue adulterant in herbal products. Food Addit Contam Part A Chem Anal Control Expo Risk Assess. 2017;34(3):330-4.

14. Wollein U, Eisenreich W, Schramek N. Identification of novel sildenafil-analogues in an adulterated herbal food supplement. J Pharm Biomed Anal. 2011;56(4):705-12.

15. Patel DN, Li L, Kee CL, Ge X, Low MY, Koh HL. Screening of synthetic PDE-5 inhibitors and their analogues as adulterants: Analytical techniques and challenges. J Pharm Biomed Anal. 2014;87:176-90.

16. Lee JH, Park HN, Park OR, Kim NS, Park SK, Kang H. Screening of illegal sexual enhancement supplements and counterfeit drugs sold in the online and offline markets between 2014 and 2017. Forensic Sci. 2019;298:10-19.

17. Guo JB, Xu Y, Huang ZB, He QH, Liu SW. Development of an immunoassay for rapid screening of vardenafil and its potential analogues in herbal products based on a group-specific monoclonal antibody. Anal Chim Acta. 2010;658(2):197-203.

18. Cai Y, Cai TG, Shi Y, Cheng XL, Ma LY, Ma SC, et al. Simultaneous determination of eight PDE5-is potentially adulterated in herbal dietary supplements with TLC and HPLC-PDA-MS methods. Chromatogr Relat Technol. 2010;33(13):1287-306.

\section{تحديد مثبطات ونظائر إنزيم الفوسفوديستيراز من النوع 5 (PDE-5) كمو اد غشّ في منتجات عشبية مختارة باستخلام الكروماتوغرافيا الغازية ـ مطياف تأثير الكتلة الإلكترونية (GC-EI-MS)}

1 أزهار الدين أوانج أحمد

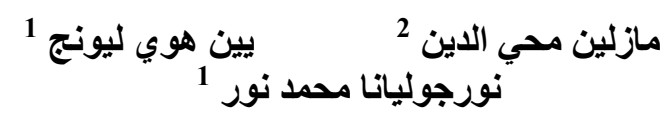

" 1 مركز السموم الوطني ، جامعة سينز ماليزيا ، 11800 بينانغ ، ماليزيا

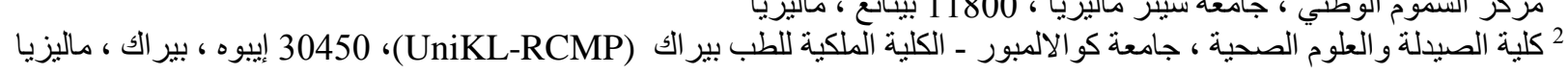

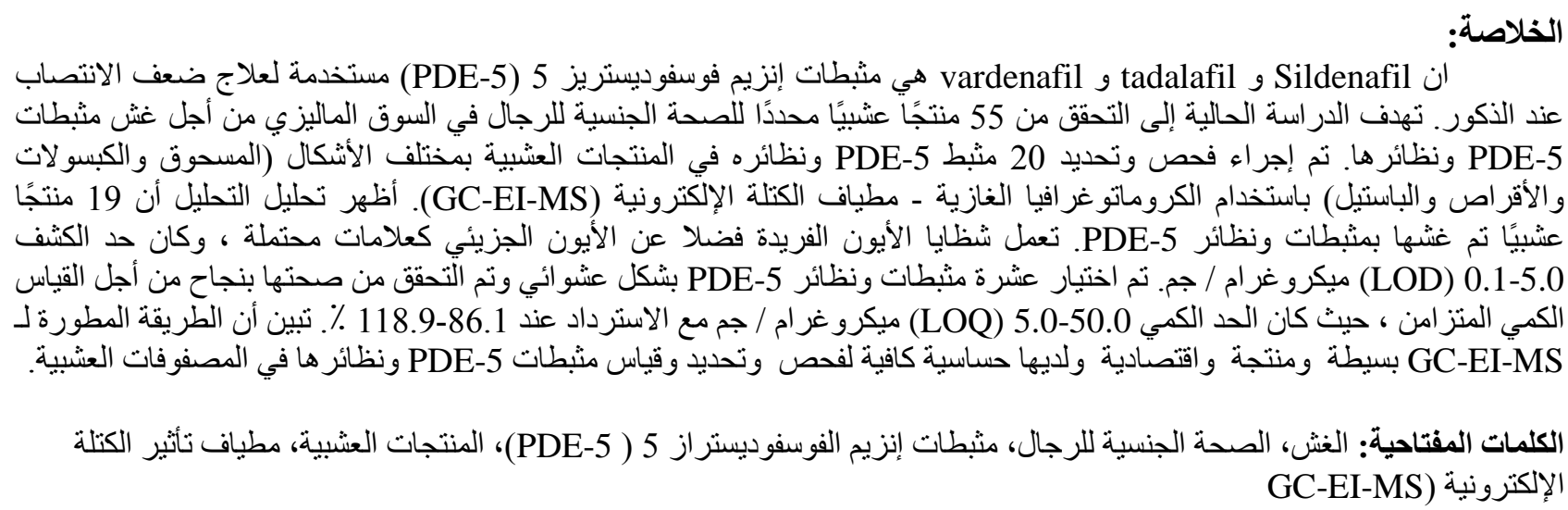

